\title{
ANALISIS EFEKTIVITAS PERATURAN KEMENTERIAN KEUANGAN NOMOR 169/PMK.010/2015 (PMK-169) \\ (STUDI EMPIRIS ATAS PERUSAHAAN PUBLIK YANG TERDAFTAR DI BURSA EFEK INDONESIA PERIODE 2015-2016)
}

\author{
Arfah Habib Saragih \\ Departemen IImu Administrasi Fiskal, Fakultas IImu Administrasi, Universitas Indonesia, Depok, Indonesia \\ arfah.habib11@ui.ac.id, arfah.habib.saragih@gmail.com
}

\begin{tabular}{|c|c|}
\hline INFO ARTIKEL & ABSTRAK/ABSTRACK \\
\hline $\begin{array}{l}\text { Histori Artikel : - } \\
\text { Tgl. Masuk : - } \\
\text { Tgl. Diterima : - } \\
\text { Tersedia Online : } 19 \text { desember } \\
2018\end{array}$ & $\begin{array}{l}\text { State revenue from the taxation sector remains dominating over } \\
\text { revenue from other sources. This revenue will be constantly } \\
\text { increased in the future. In so doing, the Government has issued } \\
\text { the Minister of Finance Regulation Number } 169 / P M K .010 / 2015 \\
\text { (PMK-169). This regulation sets the debt-to-equity ratio } \\
\text { allowable for firms in general at four to one (4:1) and has been }\end{array}$ \\
\hline $\begin{array}{l}\text { Keywords: } \\
\text { State revenue, thin capitalization, } \\
\text { debt-to-equity ratio, tax } \\
\text { avoidance, effective tax rates }\end{array}$ & $\begin{array}{l}\text { effective from tax year 2016. This is necessary to avoid thin } \\
\text { capitalization practice that can lower state revenue from the } \\
\text { taxation sector as it opens a tax avoidance opportunity for firms } \\
\text { through interest-based debt. This research was intended to } \\
\text { analyse the effectiveness of PMK-169 for firms listed on the } \\
\text { Bursa Efek Indonesia over } 2015 \text { (before) and } 2016 \text { (after). By } \\
\text { employing paired sample t-test analysis technique on } 316 \\
\text { observations of } 158 \text { firms, it was proven that there was a } \\
\text { significant difference in the debt-to-equity ratio as well as tax } \\
\text { avoidance before and after the enactment of the regulation. } \\
\text { The implication of this finding is that PMK-169 as a debt control } \\
\text { regulation is considered effective to implement. }\end{array}$ \\
\hline
\end{tabular}

\section{PENDAHULUAN}

Penerimaan pemerintah dari sektor perpajakan masih menduduki peringkat teratas dan akan terus ditingkatkan. Berbagai usaha dilakukan pemerintah untuk meningkatkan penerimaan pajak tersebut yang salah satu caranya adalah dengan mengeluarkan Peraturan Kementerian Keuangan Nomor 169/PMK.010/2015 (PMK169) tentang Penentuan Besarnya Perbandingan antara Utang dan Modal Perusahaan untuk Keperluan Perhitungan Pajak Penghasilan (PPh). PMK-169 ini menetapkan bahwa perbandingan debt to equity ratio (DER) yang diperkenankan bagi perusahaan pada umumnya adalah empat banding satu (4:1). Dengan kata lain, perbandingan utang terhadap total aset maksimal adalah $80 \% \quad$ (Peraturan Kementerian Keuangan, 2015).

Tujuan dikeluarkannnya PMK-169 ini adalah untuk membatasi proporsi debt to equity ratio (DER) dan menghindari thin capitalization. Thin capitalization dicirikan dengan tingginya proporsi utang berbasis bunga terhadap modal (OECD, 2012). Tingginya DER mengindikasikan semakin lebarnya celah penghindaran pajak yang dapat dimanfaatkan oleh perusahaan melalui beban bunga atas utang yang dapat dijadikan sebagai pengurang pada perhitungan pajak penghasilan. Dengan kata lain, tingginya DER berasosiasi dengan tingginya tingkat penghindaran pajak (Dyreng et al., 2008 dan Graham dan Tucker, 2006). Besarnya jumlah utang berbasis bunga akan berdampak pada kecilnya jumlah 
pajak yang dibayarkan kepada pemerintah yang pada akhirnya akan menurunkan penerimaan pajak negara. Dengan ditekannya perbandingan rasio utang terhadap modal, diharapkan semakin kecil pula kemungkinan penghindaran pajak yang dilakukan oleh perusahaan melalui mekanisme struktur permodalan thin capitalization.

PMK-169 ini efektif mulai berlaku sejak tahun pajak 2016. Namun, pada praktiknya biasanya perusahaan membutuhkan waktu untuk beradaptasi dengan peraturan baru yang ditetapkan oleh pemerintah. Hal ini kemungkinan besar akan mengakibatkan kurang efektifnya penerapan peraturan pada tahun diberlakukannya peraturan tersebut. Berdasarkan latar belakang tersebut, penulis tertarik untuk membuktikan secara empiris dan kuantitatif untuk mengambil kesimpulan secara umum mengenai keefektifan PMK169 untuk menurunkan rasio utang terhadap modal dan penghindaran pajak perusahaan yang terdaftar di Bursa Efek Indonesia tahun 2015 dan 2016.

Dengan demikian, permasalahan dalam penelitian ini ada dua yakni: 1. Apakah terdapat perbedaan yang signifikan pada rasio utang terhadap modal perusahaan yang terdaftar pada Bursa Efek Indonesia sebelum dan sesudah diberlakukannya PMK169 dan 2. Apakah terdapat perbedaan yang signifikan pada tingkat penghindaran pajak perusahaan yang terdaftar pada Bursa Efek Indonesia sebelum dan sesudah diberlakukannya PMK-169. Tujuan penelitian ini adalah untuk menjawab kedua permasalahan tersebut. Oleh karena PMK169 ini berlaku per tahun pajak 2016, maka, tahun penelitian dibatasi pada tahun 2015 (sebelum) dan 2016 (sesudah) agar lebih relevan untuk mencapai tujuan penelitian.

Signifikansi dan kontribusi dari penelitian ini di antaranya menambah literatur penelitian mengenai rasio utang terhadap modal serta penghindaran pajak. Selain itu, riset ini juga meningkatkan bukti empiris atas event study untuk keefektifan peraturan yang dikeluarkan oleh pemerintah. Temuan dari penelitian ini diharapkan dapat memberi masukan bagi pemerintah untuk meninjau kembali aturan pembatasan utang dan efektivitasnya dalam menurunkan debt to equity ratio dan tingkat penghindaran pajak perusahaan publik yang terdaftar di Bursa Efek Indonesia.

\section{KERANGKA TEORITIS DAN PENGEMBANGAN HIPOTESIS}

Pada penulisan penelitian ini, kerangka teoretis yang digunakan adalah teori keagenan, yang didukung dengan konsep lainnya dari berbagai penelitian yang telah dilakukan sebelumnya beserta landasan hukum peraturan perpajakan itu sendiri.

Teori Keagenan

Teori yang digunakan dalam penelitian ini adalah teori keagenan yang dikemukakan oleh Jensen dan Meckling (1976) dan Zimmerman (1978). Dalam teori keagenan, terdapat beberapa pihak yang sepakat dalam melakukan kontrak, yakni pihak principal dan agent. Principal merupakan pihak yang memberikan wewenang, sementara agent adalah pihak yang dipercaya untuk diberikan wewenang oleh principal. Dalam praktiknya, antara principal dan agent tidak selalu sejalan, terkadang terdapat perbedaan kepentingan antara principal dengan agent. Konflik kepentingan yang menjadi fokus penelitian ini adalah konflik antara manajemen perusahaan publik dengan otoritas perpajakan sebagai representasi dari pemerintah. Konflik ini terjadi karena manajemen perusahaan berupaya untuk menghindari pembayaran pajak yang salah satunya dengan thin capitalization (DER tinggi) sedangkan pemerintah ingin mengoptimalkan penerimaan pajak dari korporasi dengan cara membatasi thin capitalization dengan memberlakukan Peraturan Kementerian Keuangan Nomor 169/PMK.010/2015 (PMK-169).

Peraturan Kementerian Keuangan Nomor 169/PMK.010/2015 (PMK-169)

Peraturan Kementerian Keuangan Nomor 169/PMK.010/2015 (PMK-169) tentang Penentuan Besarnya Perbandingan antara Utang dan Modal Perusahaan untuk Keperluan Perhitungan Pajak Penghasilan (PPh) adalah jawaban atas peraturan menteri keuangan yang sebelumnya telah 
tertunda 30 tahun lebih. PMK-169 ini menetapkan bahwa perbandingan utang dan modal yang diperkenankan bagi perusahaan pada umumnya adalah maksimal empat banding satu (4:1). Dengan kata lain, perbandingan utang terhadap aset maksimal adalah 80\%. PMK-169 resmi ditetapkan dan diundangkan pada 9 September 2015. Namun, berdasarkan PMK-169 Pasal 7, disebutkan bahwa ketentuan ini mulai berlaku sejak Tahun Pajak 2016. Yang dikecualikan dari PMK-169 ini adalah wajib pajak bank, lembaga pembiayaan, asuransi dan reasuransi, pertambangan minyak dan gas bumi, pertambangan umum, dan pertambangan lainnya, serta bidang infrastruktur karena nature dari bisnisnya memang didominasi oleh pendanaan dalam bentuk utang.

\section{Thin Capitalization}

Thin capitalization adalah bentuk struktur modal di mana pembiayaan perusahaan lebih didominasi oleh utang daripada modal ekuitas perusahaan (Taylor et al., 2010 and OECD, 2012). Pembiayaan dalam bentuk utang seringkali lebih disukai oleh perusahaan karena adanya insentif pajak berupa tax shield atas interest expense (Graham and Harvey, 2001; Graham and Tucker, 2006). Dominannya jumlah utang berbasis bunga menyebabkan semakin besarnya beban bunga yang dapat dijadikan sebagai pengurang pada perhitungan taxable income (Slemrod, 2001; Rego, 2003; Fuest and Hemmelgam, 2005). Dampaknya, jumlah pajak yang dibayarkan oleh perusahaan ke negara menjadi lebih kecil sehingga akan mengurangi penerimaan pajak negara.

\section{Debt to Equity Ratio}

Salah satu rasio yang digunakan untuk menilai struktur modal adalah DER (Debt to Equity Ratio). DER dihitung sebagai perbandingan antara utang dan ekuitas pemegang saham. Rasio ini menunjukkan seberapa besar perusahaan menggunakan utang dan menjelaskan proporsi besarnya sumber pendanaan jangka pendek dan jangka panjang terhadap penilaian aset perusahaan. Rasio ini juga menunjukkan kemampuan modal sendiri perusahaan untuk memenuhi seluruh kewajibannya.
Tingginya DER berhubungan dengan tingginya tindakan penghindaran pajak yang dilakukan perusahaan (Gupta and Newberry, 1997; Isin, 2018; and Beladi et al., 2018). Apabila tidak dibatasi, maka perusahaan akan lebih cenderung menggunakan lebih banyak utang daripada modal karena adanya insentif pajak tax shield atas beban bunga yang muncul (Miller \& Modigliani, 1963).

Untuk menghindari hal ini, pemerintah melalui PMK-169 ingin menekan komposisi utang terhadap modal maksimal 4:1 sehingga insentif pajak tersebut dapat dikurangi. Oleh karena peraturan ini efektif berlaku pada tahun pajak 2016, tidak serta merta perusahaan langsung menurunkan DER nya. Perusahaan memerlukan waktu untuk beradaptasi menyesuaikan dengan peraturan tersebut sehingga belum dapat dipastikan arah perubahannya. Dengan demikian, hipotesis pertama yang dibangun adalah:

$\mathrm{H} 1$ : terdapat perbedaan yang signifikan pada rasio utang terhadap modal perusahaan publik yang terdaftar pada Bursa Efek Indonesia sebelum dan sesudah diberlakukannya PMK-169.

Penghindaran Pajak (Tax Avoidance)

Tax avoidance merupakan tindakan yang dilakukan perusahaan untuk mengurangi pajak yang dibayarkan secara eksplisit (Lietz, 2014; Hanlon dan Heitzman, 2010); mengurangi tarif pajak efektif kas perusahaan untuk jangka panjang (Dyreng et al., 2008); dan merupakan tindakan legal untuk mengurangi jumlah pajak terutang (Barr et al., 1977). Tax avoidance disebut tindakan legal karena dilakukan masih berada dalam koridor perundang-undangan perpajakan dengan tujuan agar laba yang diperoleh tidak terlalu tergerus oleh pembayaran pajak yang jumlahnya tidak sedikit.

Untuk mengukur tingkat penghindaran pajak perusahaan, indikator yang sering digunakan adalah Effective Tax Rates (ETR) (Richardson dan Lanis, 2007). ETR memberikan informasi lugas tentang seberapa besar sebenarnya pajak yang dibayarkan ke pemerintah. ETR merupakan efek kumulatif dari berbagai insentif pajak 
dan perubahan tarif pajak perusahaan (Richardson and Lanis, 2007 and McGuire et al., 2014). ETR dapat dihitung sebagai perbandingan nilai antara beban pajak penghasilan dan book income.

Salah satu cara yang yang dapat digunakan perusahaan untuk melakukan tax avoidance adalah melalui thin capitalization (Taylor and Richardson, 2013 and Lietz, 2014). Thin capitalization memberikan ruang bagi perusahaan untuk memperkecil jumlah pajak yang dibayarkan karena adanya beban bunga atas utang sebagai pengurang pajak penghasilan. Untuk menghindari hal ini, pemerintah melalui PMK-169 ingin menekan praktik thin capitalization sebagai tindakan penghindaran pajak perusahaan. Oleh karena peraturan ini efektif berlaku pada tahun pajak 2016, tidak serta merta perusahaan langsung menurunkan aktivitas thin capitalization-nya. Perusahaan memerlukan waktu untuk beradaptasi menyesuaikan dengan peraturan tersebut sehingga belum dapat dipastikan arah perubahannya. Dengan demikian, hipotesis kedua yang dibangun adalah:

$\mathrm{H} 2$ : Terdapat perbedaan yang signifikan pada tingkat penghindaran pajak perusahaan publik yang terdaftar pada Bursa Efek Indonesia sebelum dan sesudah diberlakukannya PMK-169.

\section{METODOLOGI PENELITIAN}

Populasi, Sampel, dan Data Penelitian

Bagian ini menjabarkan metode yang digunakan untuk menjawab tujuan riset. Populasi dalam riset ini adalah semua perusahaan yang ada di Indonesia. Sedangkan sampel riset yang digunakan adalah perusahaan yang terdaftar di Bursa Efek Indonesia. Periode penelitian selama dua tahun, yakni 2015 dan 2016. Kedua tahun ini dipilih karena relevan untuk menggambarkan keadaan sebelum dan sesudah diberlakukannya PMK-169 (efektif per tahun pajak 2016).

Adapun teknik pengambilan sampel adalah dengan purposive sampling method dengan kriteria-kriteria sebagai berikut: 1 . Perusahaan dengan tahun fiskal yang berakhir pada 31 Desember; 2 . Tidak memiliki nilai utang maupun modal yang negatif; 3. Memiliki nilai ETR kurang dari $100 \%$; 4. Memiliki data yang lengkap untuk tahun 2015 dan 2016; dan 5. Bukan merupakan wajib pajak bank, lembaga pembiayaan, asuransi dan reasuransi, pertambangan minyak dan gas bumi, pertambangan umum, dan pertambangan lainnya, serta bidang infrastruktur (sesuai PMK-169 yang mengecualikan jenis wajib pajak ini). Dengan demikian, total sampel akhir yang digunakan dalam riset ini berjumlah 316 observasi (yang masingmasing berjumlah 158 perusahaan untuk tahun 2015 dan 2016). Jenis data yang digunakan adalah data sekunder yang diperoleh dari laporan keuangan perusahaan dan www.idx.co.id.

\section{Operasionalisasi Variabel}

Data sekunder yang diperoleh diolah dengan menggunakan teknik analisis paired sample t-test, dengan bantuan software SPSS dengan tingkat signifikansi 5\%. Paired sample t-test adalah uji beda untuk dua kelompok berpasangan yang mendapat perlakuan berbeda. Uji ini adalah uji yang tepat untuk membuktikan hipotesis yang telah dibangun sebelumnya, apakah terdapat perbedaan yang signifikan pada rasio utang terhadap modal serta penghindaran pajak sebelum (tahun 2015) dan sesudah (tahun 2016) diberlakukannya PMK-169, yakni sebagai berikut: $H 1$ : Terdapat perbedaan yang signifikan pada rasio utang terhadap modal perusahaan publik yang terdaftar pada Bursa Efek Indonesia sebelum dan sesudah diberlakukannya PMK-169 dan H2: Terdapat perbedaan yang signifikan pada tingkat penghindaran pajak perusahaan publik yang terdaftar pada Bursa Efek Indonesia sebelum dan sesudah diberlakukannya PMK-169. Untuk hipotesis pertama, ukuran variabel yang digunakan adalah DER - debt to equity ratio dan untuk hipotesis kedua, ukuran variabel yang digunakan untuk penghindaran pajak adalah ETR - effective tax rate, masing-masing untuk tahun 2015 dan 2016.

\section{HASIL DAN PEMBAHASAN}


Pada bagian ini, peneliti akan membahas hasil pengolahan data riset dengan bantuan software SPSS untuk akhirnya menguji hipotesis pertama dan kedua, serta menjawab permasalahan riset apakah terdapat perbedaan yang signifikan pada rasio utang terhadap modal dan penghindaran pajak sebelum (tahun 2015) dan sesudah (tahun 2016) diberlakukannya PMK-169.

\section{Statistik Deskriptif}

Dari Tabel 1, terlihat bahwa nilai maksimum DER pada tahun 2015 adalah sebesar 8,19 dan menurun pada tahun 2016 menjadi 6,25. Hal ini mengindikasikan bahwa masih ada perusahaan yang belum menerapkan PMK-169 sepenuhnya (masih melebihi rasio 4:1), akan tetapi perusahaan tersebut sudah
Sama halnya dengan DER, nilai rata-rata ETR juga mengalami penurunan dari $27,76 \%$ menjadi $25,14 \%$. Semakin tinggi DER, semakin tinggi juga indikasi terjadinya penghindaran pajak, yang tercermin dari nilai ETR yang rendah. Walaupun nilai ratarata ETR turun, bukan berarti terjadi penghindaran pajak karena nilai $25,14 \%$ masih berada di atas batas tarif pajak yang berlaku di Indonesia untuk perusahaan sebesar $25 \%$.

Paired Samples Test atas Rasio Utang terhadap Modal (Debt to Equity Ratio-DER)

Berdasarkan hasil pada Tabel 2 di bawah, terlihat bahwa perbedaan nilai ratarata untuk DER

Tabel 2 Paired Samples Test atas DER

\begin{tabular}{|c|c|c|c|c|c|c|c|c|}
\hline \multirow{4}{*}{$\begin{array}{c}\text { DER } 2015 \text { - } \\
\text { DER } 2016\end{array}$} & \multicolumn{5}{|c|}{ Pairred Differences } & \multirow[t]{4}{*}{$t$} & \multirow[t]{4}{*}{$d f$} & \multirow{4}{*}{$\begin{array}{c}\text { Sig. } \\
(2- \\
\text { tailed) }\end{array}$} \\
\hline & \multirow[t]{3}{*}{ Mean } & Std. & Std. & $95 \%$ & $95 \%$ & & & \\
\hline & & Dev. & Error & Conf. & Conf. & & & \\
\hline & & & Mean & Lower & Upper & & & \\
\hline Pair 1 & 0,0897 & 0,6027 & 0,0479 & $-0,005$ & 0,1843 & 1,870 & 157 & 0,063 \\
\hline
\end{tabular}

menunjukkan niat baik untuk menurunkan DER tersebut mendekati angka 4:1 dari 8,19 menjadi 6,25. Dilihat dari nilai rata-rata DER tahun 2015 dan 2016, terjadi penurunan nilai dari 1,28 ke 1,19 , yang secara garis besar berarti perusahaan sampel dalam riset ini sudah bereaksi menunjukkan kepatuhan pada PMK-169 karena nilainya sudah berada di bawah 4:1. Perusahaan sampel beroperasi pada tingkat DER yang diperkenankan oleh pemerintah, yang berarti tidak secara aktif menerapkan praktik thin capitalization.

Tabel 1 Statistik Deskriptif

\begin{tabular}{|l|c|c|c|c|}
\hline & \multicolumn{2}{|c|}{2015} & \multicolumn{2}{c|}{2016} \\
\hline & DER & ETR & DER & ETR \\
\hline Mean & 1.2811 & 0.2776 & 1.1914 & 0.2514 \\
\hline Minimum & 0.0087 & 0.0014 & 0.0123 & 0.0025 \\
\hline Maximum & 8.1945 & 0.8842 & 6.2467 & 0.9220 \\
\hline $\begin{array}{l}\text { Standard } \\
\text { Deviation }\end{array}$ & 1.1540 & 0.1872 & 1.0090 & 0.1539 \\
\hline Observation & 158 & 158 & 158 & 158 \\
\hline
\end{tabular}

Sumber: Olah Data Penulis dengan SPSS sesudah diberlakukannya PMK-169 adalah turun sebesar 0,0897 (dari 1,2811 menjadi $1,1914)$ dengan nilai yang signifikan pada level 5\% (signifikansi one-tailed 3,15\%). Dengan demikian, hipotesis pertama diterima. Hal ini menunjukkan bahwa terdapat perbedaan yang signifikan pada rasio utang terhadap modal perusahaan yang terdaftar pada Bursa Efek Indonesia sebelum dan sesudah diberlakukannya PMK169.

PMK-169 resmi ditetapkan dan diundangkan pada 9 September 2015. Namun, berdasarkan PMK-169 Pasal 7, disebutkan bahwa ketentuan ini mulai berlaku sejak Tahun Pajak 2016. Pemberlakuan PMK-169 pada tahun pajak 2016 dinilai telah efektif diimplementasikan oleh perusahaan-perusahaan publik sampel 
yang terdaftar pada Bursa Efek Indonesia karena berdasarkan hasil olah data, ditemukan bahwa terdapat penurunan nilai DER yang signifikan sebelum dan sesudah diberlakukannya peraturan tersebut. Hal ini terjadi dimungkinkan karena telah diundangkannya peraturan ini pada jauh hari sebelum tanggal efektif berlakunya PMK-169 ini sehingga perusahaan sudah bersiap untuk beradaptasi menerapkan peraturan tersebut. Hasil temuan ini diharapkan dapat menjadi masukan bagi pembuat kebijakan agar senantiasa mengumumkan peraturan baru jauh hari sebelum tanggal efektif berlaku

ditetapkan. Tujuannya agar perusahaan dapat menyiapkan diri untuk menerapkan peraturan tersebut sehingga peraturan yang dibuat oleh pembuat kebijakan menjadi lebih efektif untuk dilaksanakan.

\section{Paired Samples Test atas Penghindaran Pajak (Effective Tax Rates-ETR)}

Berdasarkan hasil pada Tabel 3, terlihat bahwa perbedaan nilai rata-rata untuk ETR sebelum dan sesudah diberlakukannya PMK169 adalah turun sebesar 0,0262 (dari 0,2776 menjadi 0,2514 ) dengan nilai yang signifikan pada level 5\% (signifikansi onetailed 2,55\%). Dengan demikian, hipotesis 2 diterima. Hal ini menunjukkan bahwasanya terdapat -

perbedaan yang signifikan pada tingkat penghindaran pajak perusahaan yang terdaftar pada Bursa Efek Indonesia sebelum dan sesudah diberlakukannya PMK-169.

Tingkat penghindaran pajak yang tinggi tercermin dari nilai ETR yang rendah (di bawah 25\%). Pada kasus ini, walaupun nilai ETR menurun signifikan dari tahun 2015 ke tahun 2016 bukan berarti terjadi penghindaran pajak yang signifikan oleh perusahaan dalam sampel. Hal ini terjadi karena nilai rata-rata ETR masih berada di atas angka 25\%. Hasil temuan ini menyiratkan bahwa PMK-169 yang diberlakukan oleh pemerintah tidak memicu perusahaan melakukan penghindaran pajak secara signifikan karena masih membayar pajak sesuai ketentuan tarif yang berlaku. Temuan ini diharapkan dapat menjadi umpan balik bagi pemerintah untuk membuat kebijakan perpajakan yang efektif dan efisien agar tidak semakin memperbesar celah perusahaan melakukan tindakan penghindaran pajak.

Untuk menjalankan berbagai agenda penyelenggaraan negara, pemerintah masih sangat mengandalkan penerimaan dari sektor perpajakan. Berbagai upaya dilakukan oleh pemerintah untuk mencapai target penerimaan dari sumber perpajakan dari tahun ke tahun. Salah satu upaya tersebut adalah mengeluarkan Peraturan Kementerian Keuangan Nomor 169/PMK.010/2015 (PMK-169) tentang Penentuan Besarnya Perbandingan antara Utang dan Modal Perusahaan untuk Keperluan Perhitungan Pajak Penghasilan (PPh). PMK-169 ini menetapkan bahwa perbandingan debt to equity ratio (DER) yang diperkenankan bagi perusahaan pada umumnya adalah empat banding satu (4:1). Dengan kata lain, perbandingan utang terhadap total aset maksimal adalah $80 \%$ (Peraturan Kementerian Keuangan, 2015).

Tujuan dikeluarkannnya PMK-169 ini adalah untuk membatasi proporsi debt to equity ratio (DER) dan menghindari thin capitalization yang pada akhirnya akan meningkatkan penerimaan dari sektor perpajakan perusahaan publik yang terdaftar di Bursa Efek Indonesia. PMK-169 ini dapat dikatakan efektif diberlakukan apabila terjadi penurunan DER menuju perbandingan 4:1 yang signifikan (sebagaimana ditemukan pada pengujian hipotesis pertama). Hal ini berarti, pada periode sebelumnya, rasio DER cenderung tinggi dan setelah adanya peraturan ini pada tahun 2016 rasio DER menurun yang menandakan perusahaan publik sampel yang terdaftar di Bursa Efek Indonesia bereaksi terhadap PMK-169 tersebut.

Tujuan lain dari dikeluarkan PMK-169 ini tentu adalah menurunkan tingkat penghindaran pajak. Semakin agresif perusahaan publik melakukan penghindaran 
pajak, maka semakin menurun pula jumlah pajak yang dibayarkan perusahaan publik tersebut ke pemerintah (otoritas perpajakan). Dengan dibatasinya rasio utang terhadap modal, menjadikan semakin kecil insentif pajak yang muncul dari beban bunga yang dapat dikurangkan dari pengurang pajak perusahaan sehingga hal ini dapat mengurangi praktik penghindaran pajak di level pajak perusahaan publik. Sesuai hasil pada pengujian hipotesis kedua, ditemukan bukti bahwa hipotesis kedua diterima yang artinya terdapat perbedaan yang signifikan antara penghindaran pajak sebelum dan sesudah PMK-169 ini diterapkan.

Berdasarkan hasil pembahasan di atas, ditemukan hasil bahwa hipotesis pertama dan kedua diterima. Dengan kata lain, diperoleh bukti empiris bahwa terdapat perbedaan yang signifikan pada nilai rasio utang terhadap modal serta penghindaran pajak pada saat sebelum dan sesudah diberlakukannya peraturan tersebut. Dari hipotesis pertama, terdapat perbedaan yang signifikan pada rasio utang terhadap modal perusahaan yang terdaftar pada Bursa Efek Indonesia sebelum (2015) dan sesudah (2016) diberlakukannya PMK-169. Dan dari hipotesis kedua, juga ditemukan perbedaan yang signifikan pada tingkat penghindaran pajak perusahaan yang terdaftar pada Bursa

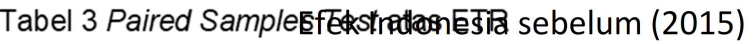

\begin{tabular}{|c|c|c|c|c|c|c|c|c|}
\hline \multirow{2}{*}{$\begin{array}{l}\text { ETR } 2015 \text { - } \\
\text { ETR } 2016\end{array}$} & \multicolumn{5}{|c|}{ Pairred Differences } & \multirow[t]{2}{*}{$t$} & \multirow[t]{2}{*}{$d f$} & \multirow{2}{*}{$\begin{array}{c}\text { Sig. } \\
(2- \\
\text { tailed) }\end{array}$} \\
\hline & Mean & $\begin{array}{l}\text { Std. } \\
\text { Dev. }\end{array}$ & $\begin{array}{l}\text { Std. } \\
\text { Error } \\
\text { Mean }\end{array}$ & $\begin{array}{l}\text { 95\% } \\
\text { Conf. } \\
\text { Lower }\end{array}$ & $\begin{array}{l}\text { 95\% } \\
\text { Conf. } \\
\text { Upper }\end{array}$ & & & \\
\hline Pair 1 & 0,0262 & 0,1669 & 0,013 & $-0,000$ & 0,052 & 1,970 & 157 & 0,051 \\
\hline
\end{tabular}

Sumber: Olah Data Penulis dengan SPSS

PMK-169 ini tidak memicu perusahaan publik melakukan penghindaran pajak secara signifikan karena masih membayar pajak sesuai ketentuan tarif yang berlaku, yakni sebesar rata-rata $25 \%$. Hasil penelitian ini memperkuat pernyataan dan hasil temuan yang dikemukakan oleh Gupta and Newberry, 1997; Isin, 2018; and Beladi et al., 2018, dimana pergerakan rasio utang terhadap modal diasosiasikan pergerakan penghindaran pajak. Semakin tinggi rasio utang terhadap modal maka semakin tinggi pula tindakan penghindaran pajak yang dilakukan perusahaan. Dengan dibatasinya DER dengan peraturan PMK-169 ini, maka diharapkan semakin terbatas juga ruang perusahaan publik untuk melakukan aktivitas penghindaran pajak sehingga penerimaan pemerintah dari sektor perpajakan dapat ditingkatkan dan berkesinambungan.

\section{KESIMPULAN}

dan sesudah (2016) diberlakukannya PMK169. Dengan demikian, dari temuan ini dapat disimpulkan bahwa PMK-169 sebagai regulasi pembatasan utang dapat dinilai efektif diterapkan oleh perusahaan sampel yang terdaftar di Bursa Efek Indonesia periode 2015-2016.

\section{IMPLIKASI DAN KETERBATASAN}

Implikasi dari temuan ini adalah bahwa PMK-169 sebagai peraturan pembatasan utang telah dinilai efektif diimplementasikan. Hasil temuan ini diharapkan dapat menjadi masukan bagi pembuat kebijakan agar dapat mengumumkan peraturan baru jauh hari sebelum tanggal efektif berlaku ditetapkan. Tujuannya agar perusahaan dapat menyiapkan diri untuk menerapkan peraturan tersebut sehingga peraturan yang dibuat oleh pembuat kebijakan menjadi lebih efektif untuk dilaksanakan. 
Selain itu, pemerintah juga perlu memperhitungkan dengan teliti dampak dari berlakunya peraturan baru terhadap berbagai aspek yang terkait. Pemerintah diharapkan dapat membuat kebijakan perpajakan yang efektif dan efisien agar tidak semakin memperbesar celah perusahaan melakukan tindakan penghindaran pajak. Temuan dalam penelitian ini memberi implikasi teoretis dengan menambah literatur mengenai rasio utang terhadap modal serta penghindaran pajak sebagai salah satu referensi untuk penelitian selanjutnya. Selain itu, riset ini juga memberikan bukti empiris atas event study untuk keefektifan peraturan yang dikeluarkan oleh pemerintah. Temuan dari penelitian ini diharapkan dapat memberi umpan balik bagi pemerintah untuk meninjau kembali aturan pembatasan utang dan efektivitasnya dalam menurunkan debt to equity ratio dan tingkat penghindaran pajak. Otoritas perpajakan sebaiknya juga melakukan pemeriksaan pajak atas perusahaan dengan rasio utang terhadap modal yang melebihi ketentuan yang berlaku, tidak hanya perusahaan yang terdaftar di Bursa Efek Indonesia, tetapi juga yang belum terdaftar. Pemeriksaan pajak secara berkala tersebut dapat memperkecil celah perusahaan untuk melakukan penghindaran pajak melalui instrumen penerbitan utang jauh melebihi modal yang dimiliki.

Otoritas perpajakan Indonesia juga dapat melakukan studi banding dengan negara lain mengenai aturan pembatasan utang yang memberikan dampak positif baik bagi perusahaan publik itu sendiri maupun bagi pendapatan negara dari sektor pajak perusahaan publik. Hal ini untuk mengetahui dampak yang timbul dari pembatasan utang terhadap modal tersebut bagi kinerja perusahaan.

Bagi perusahaan yang belum terdaftar di Bursa Efek Indonesia, sebaiknya juga dapat bergabung untuk terdaftar di Bursa Efek tersebut karena membuat perusahaan semakin mudah dalam memperoleh modal (dengan penyertaan saham dari publik) dan tidak terlalu bergantung pada utang untuk membiayai operasional maupun ekspansi bisnis perusahaan.

Penelitian ini tidak terlepas dari keterbatasan, di antaranya terbatasnya jumlah sampel perusahaan dan tahun penelitian. Penelitian selanjutnya dapat menambah jumlah sampel perusahaan berdasarkan kategori yang lebih lengkap serta tahun penelitian yang lebih panjang agar hasil riset dapat lebih tergeneralisasi dalam menilai keefektifan peraturan pembatasan utang terhadap modal ini.

\section{DAFTAR PUSTAKA}

Beladi, Hamid., Chao, Chi Chur., and Hu, May. (2018). Does tax avoidance behaviour affect bank loan contracts for Chinese listed firms? International Review of Financial Analysis, Volume 58.

Dyreng, S., Hanlon, M., and Maydew, E. (2008). Long-run corporate tax avoidance. The Accounting Review, Volume 83.

Fuest, Clemens., \& Hemmelgam, Thomas. (2005). Corporate tax poliky, foreign firm ownership and thin capitalization. Regional Science and Urban Economics. Volume 35, Issue 5.

Graham, J. R., and Harvey, C. R. (2001). The theory and practice of corporate finance: Evidence from the field. Journal of Financial Economics, Volume 60, Issue 2.

Graham, J., and Tucker, A. (2006). Tax Shelters and Corporate Debt Policy. Journal of Financial Economics Volume 81.

Gupta, S., and Newberry, K. (1997). Determinants of the variability in corporate effective tax rates: evidence from longitudinal study. Journal of Accounting and Public Policy.

Hanlon, M. and Heitzman, S. (2010). A Review of Tax Research. Journal of Accounting and Economics, Volume 50.

Isin, Adnan Anil. (2018). Tax avoidance and cost of debt: The case for loanspecific risk mitigation and public debt financing. Science Direct Journal of Corporate Finance, Volume 49. 
Jensen, Michael C. and Meckling, William

H. (1976). Theory of the Firm: Managerial Behavior, Agency Costs, and Ownership Structure. Journal of Financial Economics, October, Volume 3 , Issue 4.

Knauer, Thorsten. and Sommer, Friedrich. (2012). Interest barrier rules as a response to highly leveraged transactions: Evidence from the 2008 German business tax reform. Review of Accounting and Finance, Volume 11, Issue 2.

Lietz, G. (2014). Determinants and Consequences of Corporate Tax Avoidance. University of Munster: Institute of Accounting and Taxation.

McGuire, S.T., Wang, D., and Wilson, R.J.

(2014). Dual class ownership and tax avoidance. Accounting. Review, Volume 89.

OECD. (2012). Thin Capitalisation

Legislation: A Background Paper of Country Tax Administrations. OECD.

Rego, S. O. (2003). Tax-avoidance activities of U.S. multinational firms. Contemporary Accounting Research, Volume 20, Issue 4.

Republik Indonesia. (2015). Peraturan
Menteri Keuangan Nomor 169/PMK.010/2015 tentang Penentuan Besarnya Perbandingan antara Utang dan Modal Perusahaan untuk Keperluan Perhitungan Pajak Penghasilan.

Richardson, Grant., and Lanis, Roman. (2007). Determinants of the Variability in Corporate Effective Tax Rates and Tax Reform: Evidence from Australia. Journal of Accounting and Publik Poliky, Volume 26.

Sherif, Mohamed. and Erkol, Cennet Tuba. (2017). Sukuk and conventional bonds: shareholder wealth perspective. Journal of Islamic Accounting and Business Research, Volume 8, Issue 4.

Taylor, Grantley. and Richardson, Grant. (2013). The determinants of thinly capitalized tax avoidance structures: Evidence from Australian firms. Journal of International Accounting, Auditing and Taxation, Volume 22.

Taylor, G., Tower, G., and Van der Zahn, M. (2010). The influence of international taxation structures on corporate financial disclosure patterns. Accounting Forum, Volume 35. 